\title{
Interpolyelectrolyte Complexes of Conjugated Copolymers and DNA: Platforms for Multicolor Biosensors
}

\author{
Bin Liu and Guillermo C. Bazan* \\ Departments of Chemistry and Materials, Institute for Polymers and Organic Solids, \\ University of California, Santa Barbara, CA 93106
}

\section{Supplementary Information}

\section{Experimental Section}

General Details. ${ }^{1} \mathrm{H}$ and ${ }^{13} \mathrm{C}$ NMR spectra were collected on Varian ASM 200

MHz spectrometers. UV-Vis absorption spectra were recorded on a Shimadzu UV-2401

PC diode array spectrometer. Photoluminescence spectra were obtained using a Spex

Fluorolog 2 spectrometer, using 90 degree angle detection for solution samples.

Elemental analysis were performed by the UC Santa Barbara elemental analysis center.

Reagents were obtained from Aldrich Co., and used as received.

4,7-dibromo-2,1,3-benzothiadiazole. 2,1,3-benzothiadiazole (6.8 g, $50 \mathrm{mmol})$ in

$15 \mathrm{~mL}$ of $47 \% \mathrm{HBr}$ solution was heated to reflux while bromine $(24 \mathrm{~g}, 150 \mathrm{mmol})$ was added dropwise. At the end of the addition, an extra $10 \mathrm{~mL}$ of $\mathrm{HBr}$ was added, and the 
mixture was heated under reflux for an additional three hours. The mixture was filtered while hot, and the filtrate was washed with water, $5 \%$ sodium bicarbonate and water. The crude product was collected, dried, and recrystallized from chloroform-hexane to afford 4,7-dibromo-2,1,3-benzothiadiazole $(9.0 \mathrm{~g}, 61.2 \%)$ as yellow crystals. ${ }^{1} \mathrm{H}$ NMR $\left(\mathrm{CDCl}_{3}\right.$, $200 \mathrm{MHz}): \delta 7.72 \mathrm{ppm}$.

\section{Poly[9,9-bis(6'-bromohexyl)fluorene-co-1,4-phenylene-co-4,7-(2,1,3-}

benzothiadiazole)] (PFPB precursor). 2,7-Dibromo-9,9-bis(6'-bromohexyl)fluorene (306.8 mg, $0.475 \mathrm{mmol}$ ), 4,7-dibromo-2,1,3-benzothiadiazole (7.3 mg, $0.025 \mathrm{mmol}), 1,4-$ phenyldiboronic acid $(82.9 \mathrm{mg}, 0.5 \mathrm{mmol}), \mathrm{Pd}\left(\mathrm{PPh}_{3}\right)_{4}(8 \mathrm{mg})$ and potassium carbonate $(830 \mathrm{mg}, 6 \mathrm{mmol})$ were placed in a $25 \mathrm{~mL}$ round bottom flask. A mixture of water $(3 \mathrm{~mL})$ and THF $(6 \mathrm{~mL})$ was added to the flask and the reaction vessel was degassed. The mixture was refluxed at $85{ }^{\circ} \mathrm{C}$ for $20 \mathrm{~h}$ under nitrogen, and then precipitated into methanol. The polymer was filtered and washed with methanol and acetone, and then dried under vacuum for $24 \mathrm{~h}$ to afford the neutral PFPB precursor (180 $\mathrm{mg}, 65.9 \%)$, as a light yellow fibrous solid. ${ }^{1} \mathrm{H}$ NMR $\left(200 \mathrm{MHz}, \mathrm{CDCl}_{3}\right): \delta 7.8(\mathrm{~m}, 5 \mathrm{H}), 7.7-7.5(\mathrm{~m}, 5 \mathrm{H})$, $3.3(\mathrm{t}, 4 \mathrm{H}), 2.1(\mathrm{~m}, 4 \mathrm{H}), 1.7(\mathrm{br}, 4 \mathrm{H}), 1.3-1.2(\mathrm{~m}, 8 \mathrm{H}), 0.8(\mathrm{br}, 4 \mathrm{H})$. Elemental analysis: Calcd for $\mathrm{C}_{15.025} \mathrm{H}_{16.3} \mathrm{Br}_{0.95} \mathrm{~N}_{0.05} \mathrm{~S}_{0.025}: \mathrm{C}, 65.79 ; \mathrm{H}, 5.98 ; \mathrm{N}, 0.26$. Found: $\mathrm{C}, 64.52 ; \mathrm{H}, 5.39$; $\mathrm{N}, 0.39$. GPC (THF, polystyrene standard), $\mathrm{M}_{w}: 19,500 \mathrm{~g} / \mathrm{mol} ; \mathrm{M}_{n}: 11,000 \mathrm{~g} / \mathrm{mol}$; PDI: 1.95 . 


\section{Poly(9,9-bis(6'- $N, N, N$-trimethylammoniumbromide)hexyl)fluorene-co-1,4-}

phenylene-co-4,7-(2,1,3-benzothiadiazole)] (PFPB). Condensed trimethylamine (2 mL)

was added dropwise to a solution of the neutral precursor polymer $(50 \mathrm{mg})$ in THF (10

$\mathrm{mL}$ ) at $-78^{\circ} \mathrm{C}$. The mixture was allowed to warm up to room temperature. The precipitate

was re-dissolved by addition of water $(10 \mathrm{~mL})$. After the mixture was cooled down to -78

${ }^{\circ} \mathrm{C}$, extra trimethylamine $(2 \mathrm{~mL})$ was added and the mixture was stirred for $24 \mathrm{~h}$ at room

temperature. After removing most of the solvent, acetone was added to precipitate PFPB

(55 mg, 91.2\%) as a light yellow powder. ${ }^{1} \mathrm{H}$ NMR (200 MHz, $\left.\mathrm{CD}_{3} \mathrm{OD}\right): \delta 8.1-7.7(\mathrm{~m}$,

$10 \mathrm{H}), 3.3-3.2(\mathrm{t}, 4 \mathrm{H}), 3.1(\mathrm{~s}, 18 \mathrm{H}), 2.3(\mathrm{br}, 4 \mathrm{H}), 1.6(\mathrm{br}, 4 \mathrm{H}), 1.3(\mathrm{br}, 8 \mathrm{H}), 0.8(\mathrm{br}, 4 \mathrm{H})$.

General procedure for FRET experiments.

The oligonucleotide used in the single stranded DNA study is 5'-TR-ATC TTG

ACT ATG TGG GTG. The extent of hybridization was verified by variable temperature

absorbance spectroscopy. Fluorescence intensities were determined from the integrated

areas under emission spectra of both the donor and the acceptor (Texas Red).

Measurements were carried out in water at a fixed ss-DNA-TR concentration ([ss-DNA-

$\mathrm{TR}]=2.0 \mathrm{E}-8 \mathrm{M})$, by varying the polymer with concentration varying from $0 \mathrm{M}$ to $2.3 \mathrm{E}-$

7 M. The excitation wavelength for PFB and PFPB was chosen at $380 \mathrm{~nm}$, and the emission intensity was corrected to reflect the difference in optical density for polymers. 
The PNA used in the DNA/PNA-Cy5 study corresponds to the sequence 5'-Cy5CAG TCC AGT GAT ACG-3'. It was annealed at $2{ }^{\circ} \mathrm{C}$ below its melting temperature for 25 minutes in the presence of an equimolar amount of its complementary 15 base pair ssDNAc (5'-CGT ATC ACT GGA CTG-3') and in an identical fashion with a noncomplementary 15 base ss-DNAn (5'-ACT GAC GAT AGA CTG-3'). The absorbance of the hybridized strands was measured to determine concentration before using in FRET experiments. The extent of hybridization was checked by variable temperature absorbance spectroscopy. The overlap of the emission of PFPB and the absorption of Cy5 is shown in Figure 1.

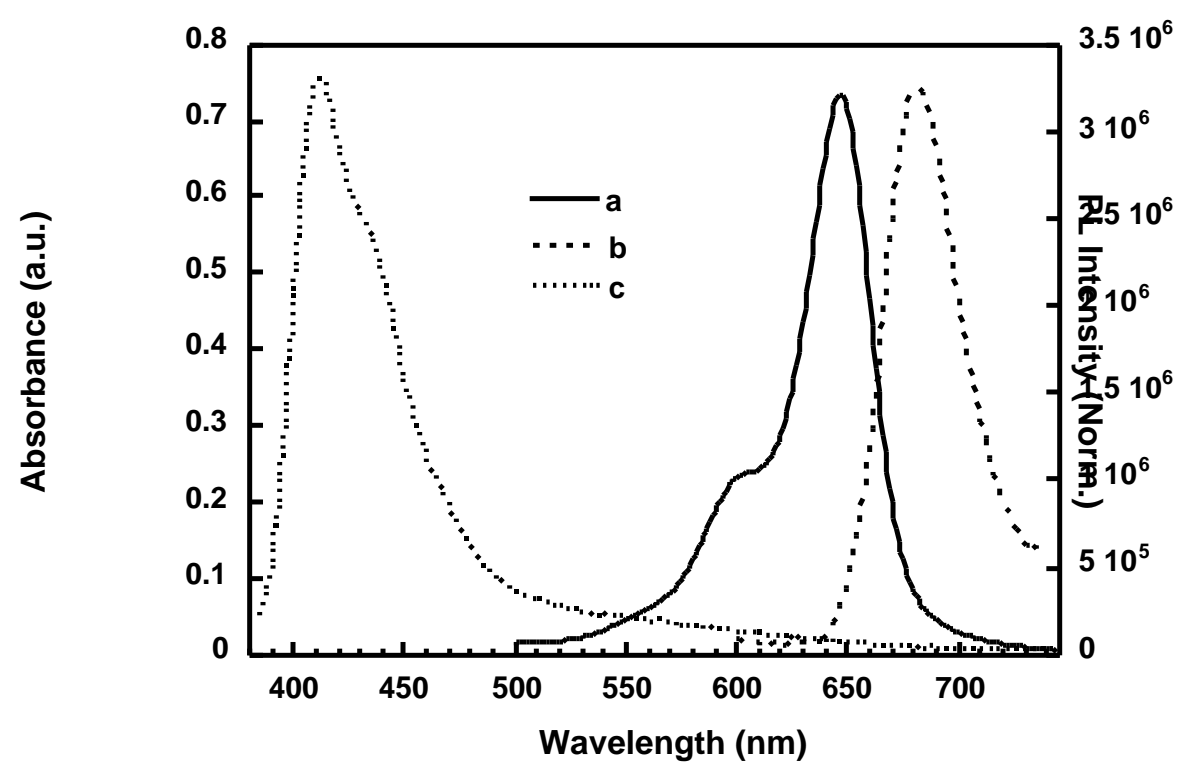

Figure 1. Normalized photoluminescence spectra of PFPB (a), the absorption (b) and emission (c) spectra of ss-DNA-Cy5 in water. 